Fr. Marek Jagodziński*

Theological Faculty KUL, Lublin

\title{
COMMUNIONAL ASPECTS OF THE DOCTRINE OF THE HOLY SPIRIT ACCORDING TO JOHN D. ZIZIOULAS
}

What deserves emphasizing in the significant theological thought of John D. Zizioulas is his ecumenical openness and deep theology saturated with communion thought, which also produces the communion perspective of the reality of the Holy Spirit. Pneumatology has its origins in the Trinitarian-ecclesial reflection, which developed the fundamental concept of the Communion of the Holy Trinity. Zizioulas completely agrees with the Orthodox Trinitarian-pneumatological vision, which critically refers to the Trinitarian contribution of the thought of St. Augustine and he presents also a communional view on the contentious issue of Filioque - emphasizing the ecumenical perspectives of this topic and of ongoing dialogues which are still trying to bring the consensus of the Churches of East and West.

The Metropolitan of Pergamon John D. Zizioulas is one of the best known Orthodox theologians. He has gained worldwide recognition for his books which are a collection of articles on the relationship between anthropology and ecclesiology, the human person, freedom, truth, communion and the ontology of otherness. ${ }^{1}$ They were published in English, which also contributed to the rapid reception of

* Fr. Prof. Dr Hab. Marek Jagodziński - The diocese of Radom, dogmatic theologian, associate professor in the Department of Orthodox Theology in the Ecumenical Section of the Institute of Theology at the Faculty of Theology of the Catholic University of Lublin, lectures at the seminary in Radom. He specializes in the theology of communication and communion. Recent monographs: Trynitarno-komunijna teologia stworzenia, Lublin 2016; Eschatologia dzisiaj, Lublin 2018; e-mail: ksemjot@tlen.pl; ORCID: 0000-0002-6957-1034

1 Being as Communion. Studies in Personhood and the Church, New York 1985; Communion and Otherness. Further Studies in Personhood and the Church, London-New York 2006. Later published: Lectures in Christian Dogmatics, London-New York 2009; The Eucharistic Communion and the World, London-New York 2011. 
his texts, full of acclaim and very critical at the same time. ${ }^{2}$ Despite the unfavourable attitude of a part of his own ecclesial community to him, his ecumenical openness $^{3}$ and systematically thought-out theology ${ }^{4}$ is definitely imbued with communion thought. ${ }^{5}$ In his lectures on dogmatics, he points out that theology begins in worshiping God and communion with Him experienced by us in the Church. ${ }^{6}$ It is therefore worthwhile to look at the truth he proclaims about the Holy Spirit, characterized by the idea of communion, which is omnipresent in Zizioulas.

\section{TRINITARIAN AND ECCLESIOLOGICAL BEGINNINGS OF PNEUMATOLOGY}

Benedict XVI wrote in his exhortation Sacramentum caritatis: "God is the perfect communion of love between the Father, the Son and the Holy Spirit." (No. 8). On the subject of contemporary Trinitarian theology, Jürgen Werbick noted that it has again become the preferred topic of theological discussion largely because the concepts of "social trinitology" (he recalls here J. Moltmann and L. Boff) seem to lead trinitology beyond the notions and models that are self-sufficient and without perspectives. The Divine tri-unity is understood here

2 Cf. K. Leśniewski, „, Kim jest czlowiek, że o nim pamiętasz...?” Podstawowe idee antropologii prawostawnej, Lublin 2015, p. 31n.

3 "John Zizioulas [...] has led many of the exchanges between Eastern and Western churches. He believes all ecumenical efforts are mutually enriching, and he expresses his gratitude to the Western churches for them. Some Eastern churches are wary of Western 'influence' and critical of those involved in such ecumenism. But Bishop John tells us, every act of ecumenism must be based in the truth and thus hear the judgment of God with repentance and in the hope of reconciliation. The whole Church eagerly looks forward to its redemption and the fulfilment of all things in Christ, so it must be the prayer of the churches 'that they may be One'" (Introduction, in: J.D. Zizioulas, Lectures..., p. xxii-xxiii).

4 Zizioulas explains clearly his approach: "our purpose [...] is to offer an interpretation rather than simply a repetition of Christian doctrine. In the inspired words of the late Father Georges Florovsky, the message of the Fathers must be phrased today 'in such a way as to secure an ecumenical, a truly universal appeal. This obviously cannot be achieved by any servile repetition of the Patristic letter [...] servility is alien both to the Bible and to the Fathers [...] The East must face and meet the challenges of the West, and the West perhaps has to pay more attention to the legacy of the East $[. .$.$] Theological tradition must be reintegrated, not simply summed up and$ accumulated'. This neopatristic synthesis, as Florovsky termed it, is the task to which Orthodox theology is called today" (J.D. Zizioulas, Lectures..., p. x).

5 See: R. Małecki, Kościót jako wspólnota. Dogmatyczno-ekumeniczne studium eklezjologii Johna Zizioulasa, Lublin 2000.

6 Cf. J.D. Zizioulas, Lectures..., p. 1.

7 See: E. Piotrowski, Traktat o Trójcy Świętej, Warszawa 2007, p. 216-218. 
as an "open Holy Trinity," as the primordial event of communication that includes also people and wants to involve them in the divine communication of love. The Divine communion of Persons here is the pre-image, the "ideal" of what koinonia means, towards which God directs all human history. In the face of this mostly "inter-personal" view, the second concept (emphasizing the first one's danger of falling into the Tritheistic imagery) proclaims that the tri-unity of God can be comprehended starting with the Trinitarian self-giving in the history of salvation, in which the Father finally expresses himself in the Son and in the Holy Spirit and offers salvation to people (Werbick here quotes K. Rahner and K. Barth). The historical-salvific concept does not oppose the social and interpersonal concept. ${ }^{8}$ Werbick emphasizes that the Son's "before" in relation to the Father in the Holy Spirit, testified by the New Testament, requires a more interpersonal interpretation if one wants to avoid a modalist threat to the Trinitarian economy in the history of salvation. ${ }^{9}$

The Church's teaching on God does not bring some new concept of God, but continues the faith of Israel modified by Jesus Christ. God is transcendent, absolutely free, personal, and manifested in history through his mandates. ${ }^{10}$ Christ is the Lord who sits at the right hand of God (cf. Ps 110:1), receives all worship and glory, but when he goes to the Father he said: "I will not leave you orphans: I will come to you. [...] And the Comforter, the Holy Spirit, whom the Father will send in my name, will teach you everything and remind you of everything I have told you." (J 14:18.26). When Christ has sat the right hand of God, the Father sends another Assistant, the Spirit of Truth. ${ }^{11}$

8 Quoting H.U. von Balthasar, J. Werbick (Trinitätslehre, in: Handbuch der Dogmatik, ed. T. Schneider, vol. 2, Düsseldorf 2000, p. 539) assesses that an attempt to clarify the Trinitarian mystery "can only be made from the perspective of polarity in the transcendentalities of any finite being and therefore cannot go beyond the convergence of two earthly non-integratable images of the Trinity which together point to one another. The inter-personal model cannot reach the material unity of God, the intra-personal model cannot present a real and lasting mutual relationship of hypostasis in God" (H.U. von Balthasar, Teologika, vol. 2: Prawda Boga, transl. J. Zychowicz, Kraków 2004, p. 36).

9 Cf. J. Werbick, Trinitätslehre..., p. 513n.

10 Cf. J.D. Zizioulas, Lectures ..., p. 40-44.

11 Cf. ibidem, p. 44. In chapter 15 of Acts of the Apostles, the Congregation of Apostles addressed a message to Christians with very meaningful words: "For we have decided, the Holy Spirit and we". (1. 28). Zizioulas comments on the words "all Scripture from God is inspired [...]". ( 2 Tim 3:16) and writes that the Church's teaching is equal to the action of the Holy Spirit. One cannot think that this is done mechanically or magically, or as an action of the Holy Spirit leading, over time, to the development and improvement of the human spirit's efforts. Rather, it must be seen as the work of the Holy Spirit being an event of communion which is concentrated in the community and has both horizontal and vertical dimensions. (Cf. ibidem, p. 10). 
The coming of the Third Person - the Holy Spirit - has initiated a new relationship between people and God. His Person verifies the presence of God himself, gives gifts and shows the power that can be the power of God alone. ${ }^{12}$ The first disciples had to find in their understanding of God a place for the experience of being accompanied by the Holy Spirit, through which Christ breaks the barriers of nature and creates the Church. ${ }^{13}$ For the Holy Spirit enables every human being to transcend limitations and to go out towards "others" regardless of natural differences. Until the coming of the Spirit of Christ, the world did not know a community that would surpass all the divisions of creation. ${ }^{14}$

Therefore we cannot continue to refer to God as Israel did without referring to the Son and the Spirit. So we have the person of Christ who called himself "the Son of God" and the person of the Holy Spirit who makes Christ present to us in the Church. ${ }^{15}$ Through the experience of this communion, the Church was led to profess faith in the Father, the Son and the Holy Spirit - and this Trinitarian formula of faith became the proper name for the God of Christians. It is therefore possible either to reject Christ's claim and remain with Israel's form of faith, or to accentuate its Trinitarian signature, which leads to a new communion of all creation through Christ. ${ }^{16}$ This Trinitarian signature appears in the New Testament in three forms: in two liturgical forms - in the context of Baptism and the Eucharist - and in a broad theological context. ${ }^{17}$

Zizioulas writes about the Holy Spirit, quoting the words of one of the hymns for Pentecost that it is He who unites the whole institution of the Church. He notes that we often overlook the fact that in the New Testament the Holy Spirit was sent to the Church after Christ's resurrection (Jn 7:39), and this is because the coming of the Spirit into the world means "the last days" (cf. Acts 2:17). He also stresses

\footnotetext{
Cf. ibidem, p. 106-108.

Cf. ibidem, p. 33.

14 Cf. ibidem, p. 45. "The Holy Spirit enables the transcendence of the limitations between the created and the uncreated. He is the Spirit of communion, of power and of life, who tears down the barriers that separate beings; he enables creation to surmount the physical impossibility of communion of created and uncreated" (J.D. Zizioulas, Lectures..., p. 136). Cf. idem, Being as Communion..., p. 110-113.

15 Cf. J.D. Zizioulas, Lectures..., p. 148-153.

16 Cf. ibidem, p. 45.

17 Cf. ibidem, p. 45-47. The ecclesial action of the Holy Spirit creates the communion of Christ. We must get rid of the conviction that the Holy Spirit acts in us as isolated individuals. This understanding of the Holy Spirit would remove the person from the community. In the Old Testament, the Spirit was given to individuals; in the New Testament, the Messiah gives the Holy Spirit to all God's people. (Cf. Acts 2:17n). Cf. ibidem, p. 11.
} 
that it is no exaggeration to identify the Kingdom of God with the Holy Spirit, ${ }^{18}$ and that this Kingdom is linked to the whole structure of its fulfilment - together with the Eucharist. Zizioulas adds that the liturgy of the Eucharist is usually approached from a Christological point of view and that the Holy Spirit is usually treated only as auxiliary - and this happens under Western influence. It is, of course, about the issue of the epiclesis..$^{19}$ The Eucharist is not simply a repetition, a copy of past events. Zizioulas recalls the words of Nikolai Kabasilas that the Eucharist - and the repetition of Christ's words - is done in narrative form, but the work of transforming gifts into the Body and Blood of Christ is the work of the Holy Spirit. The transformation therefore requires the descent of the Holy Spirit, and He comes - bringing the aforementioned "last days" into history. Christ's presence in the Eucharist is therefore not realized without its pneumatological and eschatological structure - the "real presence" of Christ presupposes and entails the gathering "in one place" of the eschatological community which the Holy Spirit maintains in its entirety. ${ }^{20}$

The Eucharist is Communion and participation in the Blood of Christ, which is "full of the Holy Spirit." We share in Christ, but at the same time - according to the anaphor of St. Basil - in the communion of the Holy Spirit, and He descends not only on the gifts offered, but also on us (the celebrant and the entire liturgical assembly). In this way the "real presence" of Christ extends to the Head and body in the unity of the Holy Spirit. The Eucharist as the communion of the Holy Spirit becomes a "communion of saints" in a double sense: a communion of holy things and a communion of holy people, becoming a mystery of love. ${ }^{21}$

The Eucharist understood in this way also leads to the transformation of the world. The Eucharist does not only direct us towards the past, but also towards the future. Thanks to the economy of the Trinity, realized in the person and work of Jesus Christ and with the participation of the Holy Spirit, space and time become capable of transformation and become carriers of life, not death. Thus the Eucharist as the "Communion of the Last Times" shows that all creation is destined in God's love to be liberated from corruption and death and to live "for ever and ever" - to the communion of creation with God. ${ }^{22}$

18 Cf. Maximus the Confessor St, Orationis dominicae brevis exposition, in: Patrologiae Cursus Completus. Series Graecae, ed. P. Migne, vol. 90, Paris 1865, c. 885.

19 See: P. Evdokimov, Duch Święty w tradycji prawosławnej, transl. M. Żurowska, Poznań 2012, p. 141-148.

20 Cf. J.D. Zizioulas, The Eucharistic Communion and the World ..., p. 74n.

21 Cf. ibidem, p. 75n.

22 Cf. ibidem, p. 80n.

TwP 14,1 (2020) 


\section{THE COMMUNION OF THE PERSONS OF THE HOLY TRINITY}

After an initial period of struggle to form the doctrine of God from the perspective of the Logos, the question of the person appeared. ${ }^{23}$ Zizioulas emphasizes that the revolutionary innovations of the Cappadocian Fathers, concerning the redefinition of the terms used, contributed the most to solving the problem of persons and unity in God. Until their time, the term "hypostasis" meant existence or substance. The Cappadocians concluded that essence and hypostasis cannot be treated as synonyms. "Substance" and "nature" mean the same and can be used to refer to unity in God, while the Latin term "substance" was referred in Greek not to "hypostasis" but to "ousia." The Cappadocians decided that "hypostasis" was to mean "person" in relation to a separate being that has a true and special existence, and is not merely a "way" or "manifestation" of another being. ${ }^{24}$

And Zizioulas insists that it is not nature that is the source of Divine Persons in God. It is the Person of the Father who "makes" God exist as the Trinity, although the "Father" himself has no meaning outside of the relationship with the Son and the Spirit, because he is the Father of "someone". This plurality and interdependence of Persons is the basis of the new ontology. One being is not the beginning or source of God's existence. It is the Father's Person who is the decisive factor, but since the "Father" implies communion, it is not possible to understand Him as an isolated being. Personal communion therefore lies at the heart of the essence of being God. ${ }^{25}$

${ }^{23}$ Cf. ibidem, p. 48-50.

24 Cf. P. Evdokimov, Duch Święty w tradycji prawosławnej ..., p. 49-63; J.D. Zizioulas, Lectures..., p. 50-52; K. Leśniewski, ,, Kim jest człowiek, że o nim pamiętasz ...? ”..., p. 45-55.

25 Cf. J.D. Zizioulas, Lectures..., p. 53. "The Metropolitan of Pergamon [...] is critical of the formula 'one nature, three persons,' which is dominant in Western theology, because from it one could conclude that God is essentially an impersonal being. [...] He believes that what Cappadocian theology has contributed, namely the identification of prosopon and hypostasis and the monarch - the Father, shifts the ontological center of gravity in the Trinity from the notion of ousia to the notion of hypostasis, because God's being is identified with a person. The focus on Persons does not diminish the unity of the Deity, because among Divine Persons there is a koinonia (community/communion), the cause of which is the Person of God the Father. A true community can be realized in the relationship of one person to another. God is a relational being. Without taking the term koinonia seriously, it would be impossible to speak of God's being. You can't talk about one God until you tell about God who is koinonia - that is, a community/community of persons in the Trinity. The essence of God has no ontological content, there is no real being outside the community/community of Persons. God exists through the event of koinonia. The Trinity is an essential ontological concept, not a concept that is added to the Divine Being. (K. Leśniewski, ,,Kim jest czlowiek, że o nim pamiętasz...?”..., p. 51). 
This makes it possible to better understand the sentence that "God is love." Christianity did not invent this truth. Plato believed that God is love in the sense that love is a stream of divine nature, as involuntary as the pouring of liquid from a cup or chalice. However, the Church rejected the concept of love as an involuntary emotion or passion and instead came to understand "God is love" in the sense of constituting God's being through personal relationships. God is Communion that is to say, love is fundamental to His being and not an addition supplementing Him. ${ }^{26}$ The fact that "God is love" means that it is the Communion of the Holy Trinity. ${ }^{27}$ God is God as Father, Son and Holy Spirit - these Persons indicate how God exists. But a person does not exist without reference to other people, in isolation from them. He is an identity born of relationships and exists only in communion with others. That is why "Father," "Son" and "Spirit" mean exceptional persons. ${ }^{28}$

\section{EVALUATION OF ST. AUGUSTINE'S CONCEPTION}

For St. Augustine, the analogy between the person of God and a single human being was important in trinitology. According to Zizioulas, the Cappadocian Fathers did not recognize the usefulness of this analogy. For Augustine, the Platonic, God is above all "the mind" and that is why the Logos comes from the

26 "It is perhaps our usual assumption that we exist first, and then that we love. However, let us imagine that our existence depends on our relationship with those we love. Our being derives from our relationship with those who love us, and if they cease to love us, we disappear. Love is this communion of relationships which give us our existence. Only love can continue to sustain us when all the material threads of life are broken and we are without any other support If these threads are not reconnected we cease to exist; death is the snapping of the last thread. Love, or communion with other persons, is stronger than death and is the source of our existence" (J.D. Zizioulas, Lectures ..., p. 53).

27 "God the Father would lose his identity and being if he did not have the Son, and the same applies to the Son and to the Spirit If we took away the communion of the Trinity to make God a unit, God would not be communion and therefore would not be love. [...] God did not become love because he loves the world, for this would imply that he became love when the world came into existence. But God is absolutely transcendent, his existence is utterly independent of the world. God is love in his very being. It is not however himself that he loves, so this is not selflove. The Father loves the Son and the Spirit, the Son loves the Father and the Spirit, the Spirit loves the Father and the Son: it is another person that each loves. It is the person, not the nature or essence, who loves, and the one he loves is also a person. Because divine love is a matter of personal communion this love is free: each person loved is free to respond to this love with love" (ibidem, p. 53n).

28 "Every person is unique, unprecedented and irreplaceable, even though he exists only through relation with others". Cf. ibidem, p. 57-64. 
Father on the path of knowledge. ${ }^{29}$ God is also the good. The Logos knows the Father as a "good" and this is how the love of this good is born. According to Augustine, the Spirit is the love of the Father and the Son. The Spirit is the third form of existence through which the Father loves the Son and the Son loves the Father. Augustine calls him nexus amoris, the "bond of love." The Father is characterized by memory, the Son is characterized by knowledge, the Spirit is love - the attribute of communion therefore belongs to the Holy Spirit, who revealed that God is communion. ${ }^{30}$ Each of the three Persons therefore has its own attribute. However, the Greek Fathers did not recognize that it is possible to describe the Divine Persons by providing them with appropriate attributes. They did not say anything about the attributes of the Son and the Spirit, nor did they try to explain the difference between Trinitarian "being born" and "coming from." 31

Recalling the distinction between the immanent Trinity and the economic Trinity, Zizioulas emphasizes that there is an element of apophatism in defining Trinitarian personal attributes. We can talk about them in relation to the economic Trinity because individual Persons have taken specific actions for us and therefore have their own particular characteristics. However, if, for example, the Spirit means love and creates communion for us, this is not necessarily because love is a specific attribute of the Spirit in the eternal Trinity. Love is therefore not an attribute of the Holy Spirit, but his free personal action, and all actions of the eternal Trinity are common. ${ }^{32}$

29 "Augustine, influenced by Platonic thought, decided that the memory is the most important aspect of the mind. Our entire existence springs from the memory, and everything we know and think about, is stored imide us, in an eternally existing storeroom of truth. Knowledge is simply the recollection of this truth; the etymology of truth (aletheia) is 'un-forgetting'. We discover the truth at the moment that knowledge re-emerges from within us. This makes memory the source of our existence" (ibidem, p. 65). Cf. ibidem, p. 10-16. Cf. ibidem, p. 70.

31 Cf. ibidem, p. 66. "The Greek Fathers did not identify the persons of the Trinity with particular characteristics, but believed memory, knowledge and love belonged to the persons of the Trinity together. God has one knowledge, one will and love, not three. So we do not have one person representing knowledge, or one person representing love, but love and knowledge are common to the three of them. [...] In order to obtain an image of a person, we need to have a communion of more than one person" (ibidem, p. 68).

32 Cf. ibidem, p. 72. "This united action is expressed in different ways within the economy, so the persons do not all do the same thing, although they always act in unison. Where the Father is, there the Son and the Spirit are; where the Son is, there the Father and the Spirit are, But the Son does not perform the work that the Father performs. Whatever the differentiated actions of God in the economy, they are not extensions of differentiations within the eternal Trinity. Western theology, however, has often turned distinctions in the economy into differentiations within the eternal Trinity, which is one reason why it became trapped in the Filioque" (ibidem, p. 73). 


\section{COMMUNION OUTLOOK ON FILIOQUE}

The Western Church says that the Holy Spirit comes from the Father and the Son. Zizioulas sees the canonical ${ }^{33}$ and theological aspect of Filioque. As a theological issue, Filioque appeared again in the theology in the twentieth century, when Russian emigration brought Slavo-philic theology to the West. The main representative of this theology, Vladimir Lossky, put Filioque at the centre of the debate and this caused the return of controversy. ${ }^{34}$

From the theological point of view, Filioque was based on the position of St. Augustine, stating that in the Trinity, the Son - as the Logos - represents the knowledge of God, while the Holy Spirit is the love of God. Then, as knowledge precedes love, so the Son preceded the Spirit. On this basis, Augustine gave priority to the Son over the Spirit and made the Son, next to the Father, the source of the Holy Spirit's origin..$^{35}$ The second basis of Filioque was the conviction that, according to Augustine's view, in God "substance" is primordial to the person. One God means the substance in which three relationships subsist: Father (memory), Son (knowledge) and Spirit (love). According to scholastic theologians, complete relationships must also be mutual, and therefore they must occur in pairs. The

33 See: ibidem, p. 75-77.

34 Cf. ibidem, p. 77.

35 Because St. Augustine understood the Holy Spirit as what was common between the Father and the Son - as their mutual gift - the source of His origin had to be sought from them both. More courageously than Eastern theologians, St. Augustine drew conclusions about God's inter-Trinitarian life. His Trinitarian model of thought, however, allows us to assume a circular rather than linear dynamic that does not go, like Eastern thought, from the Father to the Son and then to the Holy Spirit, but goes from the Father in Spirit to the Son and vice versa. Originally the profession of faith spoke of the origin of the Holy Spirit "from the Father". In the Latin translation of the symbol, the expression "Filioque" has been present in the Franconian area since the $8^{\text {th }}$ Synod in Toledo (653). Cf. Y. Congar, Wierze w Ducha Świętego. Duch Święty w ekonomii Objawienia i doświadczenie Ducha, transl. A. Paygert, t. I, Warszawa 1995, p. 157-160. Western theologians have tried to disprove the accusation that Filioque postulated two original principles of the origin of the Holy Spirit instead of one. The Second Council of Lyons taught that the Holy Spirit eternally comes from the Father and the Son not as from two principles, but as from one principle. However, there was no unification. The success achieved at the Council of Florence also did not last long, even though its teachings were in line with Greek thought by revealing the exact theological meaning of the statements "from the Father through the Son" and "from the Father and the Son" and paved the way for reconciliation. Cf. W. Kasper, Bóg Jezusa Chrystusa, transl. J. Tyrawa, Wrocław 1996, p. 267-276; B. Stubenrauch, Pneumatologia - traktat o Duchu Świętym, Kraków 1999, p. 155-159; R. Laurentin, Nieznany Duch Święty. Odkrywanie Jego doświadczenia i Jego Osoby, transl. M. Tarnowska, Kraków 1998, p. 357n, 362-364. On the contemporary Eastern pneumatology see: Y. Congar, Wierze w Ducha Świętego. Rzeka życia plynie na Wschodzie i na Zachodzie (Ap 22,1), transl. L. Rutowska, vol. III, Warszawa 1996, p. $95-102,207-251$. 
Holy Spirit cannot therefore come from one Person, but from the relationships of two Persons. If the Son is the only other Person, Filioque necessarily appears. ${ }^{36}$

Zizioulas points out that the Reformation brought a different approach to the problem of the origin of the Holy Spirit. The Protestants condemned as metaphysics any theology that speaks of the "being" of God and maintained that we know God only through His action in history - through His economic action. So if the Holy Trinity appears economically in history because the Father sends the Son and the Son sends the Spirit, the Spirit is given to us by the Son. Assuming that all our knowledge of God depends on the economy of salvation, we must agree that the Spirit is also dependent on the Son and not only on the Father. The result of such reasoning led to support the doctrine of Filioque. ${ }^{37}$

According to Zizioulas, the Protestants fell victim to the same confusion as the fourteenth-century theologians, who were unable to distinguish between two types of Trinitarian processes: "origin" and "being sent." "Origin" refers to the eternal relationship between Father, Son and Spirit. The Spirit comes directly from the Father in eternity. In the economy of salvation, on the other hand, the Son sends us the Spirit - He gives us the Spirit. Apparently the Son has something to do with the economic manifestation of the Spirit. Zizioulas recalls at this point that the Greek-speaking East used the term "origin" ( $\varepsilon \kappa \pi о \rho \varepsilon v ́ \varepsilon \tau \alpha)$ only in relation to the eternal immanent Trinity. In Latin it was not easy to distinguish these aspects precisely. From the $4^{\text {th }}$ century onwards, the Greek ekporeuetai (come from) and pemptai (be sent) were translated as procedere in the Latin texts. From the beginning, therefore, the West used Filioque both in the theological (immanent) and economic meanings - and that is why there were mutual misunderstandings that fuelled these controversies. ${ }^{38}$ The second area of difficulty was contained in the above mentioned Trinitarian analogies of Augustine. ${ }^{39}$

The East did not set the nature of God before the person. It believed that if the Father is God, then making the Son the source of the origin of the Holy Spirit on an equal footing with the Father would mean recognizing the existence of two ontological origins in the Trinity, that is, two Gods. The unity of God is thus

\footnotetext{
Cf. J.D. Zizioulas, Lectures..., p. 77.

Cf. ibidem, p. $77 \mathrm{n}$.

Cf. ibidem, p. 78.

"In the view of the Greek Fathers such arguments give no support to the Filioque. The only thing we can say about the Father, the Son and the Spirit is that the Father is Unbegotten and that he is the Father of the Son; the Son is begotten and is the Son of the Father; and the Spirit 'proceeds from' the Father and that he is the Spirit, not the Son. These characteristics, which derive from the very being of these persons, tell us how they are and thus who they are. We cannot say anything about the other characteristics that belong to each of the persons" (ibidem, p. 78).
} 
secured by the Father, who is the only source and cause from which the whole life and existence of God comes. The absolute sovereignty of God is safeguarded by the unique principle of the Father (monarchia) and Filioque would introduce a second source (arché) beside the Father. ${ }^{40}$

Zizioulas also believes that the Augustinian argument that knowledge precedes love is unjustified, so the Holy Spirit can follow the Son. He stresses that knowledge is intrinsically linked to love and communion, and therefore we can only get to know a person to the extent that we love this person, that is, we are in communion with him. ${ }^{41}$

Zizioulas concludes that Filioque can be accepted if it is understood correctly. The first point concerns the clear distinction between "origin" and "being sent" in relation to the Eternal and Economic Trinity. In the economy of salvation the Holy Spirit does indeed depend on the Son, but it is completely different in the case of the immanent Trinity, where one cannot speak of any Filioque, because there the Father is the only cause of the Spirit. However - he adds - the Greek Fathers made a distinction that allows a certain role for the Son in the eternal origin of the Holy Spirit. St. Gregory of Nyssa wrote that the difference between the Father, Son and Holy Spirit is that the Father is the cause, while the Son and Spirit are the fruits of that cause. Cause is a person, a factor taking free initiative. This distinction between cause and what is the result is most important. St. Gregory writes that the Son comes directly and right from the Cause, while the Spirit comes through Him who comes directly from the Cause, i.e. through the mediation of the Son ${ }^{42}$ This mediation of the Son in the origin of the Spirit protects the fact that the Son is only begotten, i.e. He is the only Son, and the Spirit is not another son beside Him. The mediation of the Son does not change the fact that the Holy Spirit has a direct relationship with the Father, and St. Gregory emphasizes that the mediating role of the Son in the Spirit's origin safeguards this direct relationship. So, as long as we are aware that the Son is not the cause, His role in the Spirit's origin is acceptable. In the immanent life of God, however, the Holy Spirit does not come from the Son. Because in the immanent Trinity relationships are completely ontological, the Father must be the cause or the agent. In the economy it can be said that the Spirit depends on the Son, is sent by the Son and given by the Son to the Church. ${ }^{43}$ From this it can be concluded that, in distinguishing between the eternal plane and

40 Cf. ibidem, p. 78 n.

${ }_{41}$ Cf. ibidem, p. 79.

42 Cf. św. GrzegorzzNyssy, AdAblabium, in: Patrologiae Cursus Completus. Series Graecae, vol. 45, t. II, Paris 1863, k. 133.

43 Cf. W. Hryniewicz, Duch Święty - Mistagog Bożego Królestwa, in: P. Evdokimov, Duch Święty w tradycji prawostawnej..., p. 20-23. 
the economic plane, the origin of the Spirit from the Father "and the Son" is also acceptable to the East. ${ }^{44}$

Zizioulas presents documentation of the patristic development of the controversy between East and West ${ }^{45}$ and adds that the Council of Florence (1438-1439) wanted to prevent a division of the Church on this issue and suggested that if both parties wanted to accept the expression "by the Son" instead of "from the Son", there could be a basis for consent. Neither party, however, wanted to take the decisive step. The West has established its position by accepting the expression "from the Father and the Son," and did not wish to withdraw or replace it with the expression "by the Son." Zizioulas believes, however, that the question of Filioque can be solved by the Churches of East and West, and that the dialogues undertaken can lead to success in this matter. ${ }^{46}$ Meanwhile, he stresses that we must avoid everything that might contradict the principle that in the Trinity only the Father himself is an acting cause. He writes that we can all contribute to understanding the place of Filioque in the doctrine of God as the Church did in the era of St. Maximus the Confessor. ${ }^{47}$

\section{PROSPECTS}

God has shown Himself in Jesus Christ as the mystery of extraordinary closeness, love, and gift communication - the Holy Trinity. ${ }^{48}$ John Paul II wrote in his encyclical Dominum et Vivificantem that the Holy Spirit, "proceeding from

${ }_{44}$ Cf. J.D. Zizioulas, Lectures..., p. 79n. See: chapter I in the second part of P. Evdokimov's, Duch Święty w tradycji prawosławnej, entitled „Pneumatologia Ojców w ekonomii zbawienia”, p. $115-134$.

45 See: J.D. Zizioulas, Lectures..., p. 80-82; P. Evdokimov, Duch Święty $w$ tradycji prawostawnej..., p. 77-102.

46 See: P. Evdokimov, Duch Święty w tradycji prawosławnej..., p. 102-114, 149-154.

47 Cf. J.D. Zizioulas, Lectures in Christian Dogmatics..., p. 82. "In the seventh century, as word was getting around that the Filoque being used in the West, Saint Maximus was asked for his opinion on this matter. He replied that he had looked into it, and found that the Latin-speaking Romans did not have respective words for expressing the two notions of proceeding from and sent out by (ekporeuetai and pempetai), so they used only one word, proceeds and this gave rise to confusion. In the same letter to Marinus, Saint Maximus noticed that Roman Christians referred to Saint Cyril of Alexandria, whose writings seemed to give the Filioque some support in the eternal Trinity. [...] he discussed the issue with Christians in Rome and concluded that they did not mean that the Son is the cause, so Maximus said that there was no heresy involved. That was how the situation was left in the seventh century" (ibidem, p. 80-82).

48 Cf. E. Jüngel, Gott als Geheimnis der Welt, Tübingen 1977, p. 479; J. Auer, Gott - Der Eine und Dreieine, Regensburg 1978, p. 324-332; H.U. von Balthasar, Teologika, vol. 2: Prawda Boga..., p. $117-119$. 
the Father, he directs toward the Father the sacrifice of the Son, bringing it into the divine reality of the Trinitarian communion." (No. 41). Moreover, the experience of the Church as a communion ${ }^{49}$ has made it possible to show convincingly that God's being is perfect Communion through personal relationships and inter-personal love. ${ }^{50}$ For Christians, one God has always been the Holy Trinity, Communion, and in this perspective Zizioulas shows the Holy Spirit.

Today it can be said that there are two ways of approaching the mystery of the Trinity. ${ }^{51}$ When the aim is to show unity, the reflection starts with the life process that constructs the Persons as one - this is the path that the theology of the Eastern Churches in particular follows: The Father's "monarchy" is on the top, also when one describes intra-Trinitarian relationships; the Father is the only source of divine life, so the Holy Spirit owes his being God alone - the Son has at most an intermediary function ("through"). However, when one wants to show the equality of persons as to the essence (different from one another) and see unity as justified in God - this way of thinking has become dominant in Latin theology - the Father and the Son are united in the fact that they have a function of the beginning in relation to the Holy Spirit, for how could one concretely call the relationship between the Son and the Holy Spirit differently? The function of the beginning is not fully identical in the case of the Father and the Son, as St. Augustine already observed: the Father - principium non de principio - is a beginning without beginning, the Son-principium de principio - is a beginning that has an origin. The most recent Western theology tends to assess the various explanations of the origins of the Holy Spirit as complementary ways of seeing and explaining each other, profoundly conceived but not alternatives to each other. The complementary view of the two theological narratives should be interpreted in mutual dependence according to the hermeneutics of aesthetic polyphony ${ }^{52}$ and thus even controversial pneumatological issues should not block the ecumenical rapprochement of all Christians.

49 See: E. Piotrowski, Traktat o Trójcy Świętej..., p. 257-263.

50 G. Greshake writes that the development of the theology of the Trinity would not have been possible without the experience of the Church, and without the idea of communion it would not have been possible to speak of God's being (Trójjedyny Bóg. Teologia trynitarna, transl. J. Tyrawa, Wrocław 2009, p. 46). Cf. S. Kołata, Komplementarność modeli w teologii trynitarnej, Kraków 2017, p. 175n.

51 On Greek and Latin contribution to the dogmatic theology see: Y. Congar, Wierze w Ducha Świętego. Rzeka życia plynie na Wschodzie i na Zachodzie (Ap 22,1).., p. 149-163. On the critical juxtaposition of the principles of Eastern and Western Trinitology see: P. Evdokimov, Duch Święty w koncepcji prawosławnej..., p. 96-102.

52 Cf. J. Strumiłowski, Między Bogiem a człowiekiem. Teologia relacji w kontekście późnej nowoczesności, Kraków 2018, p. 46. 


\section{BIBLIOGRAPHY}

Auer J., Gott - Der Eine und Dreieine, Regensburg 1978.

Balthasar H.U. von, Teologika, vol. 2: Prawda Boga, transl. J. Zychowicz, Kraków 2004.

Benedict XVI, Exhortation "Sacramentum caritatis" (2009).

Congar Y., Wierze w Ducha Świętego. Duch Święty w ekonomii Objawienia i doświadczenie Ducha, transl. A. Paygert, t. I, Warszawa 1995.

Congar Y., Wierzę w Ducha Świętego. Rzeka życia płynie na Wschodzie i na Zachodzie (Ap 22,1), transl. L. Rutowska, t. III, Warszawa 1996.

Evdokimov P., Duch Święty w tradycji prawosławnej, transl. M. Żurowska, Poznań 2012. Greshake G. Trójjedyny Bóg. Teologia trynitarna, transl. J. Tyrawa, Wrocław 2009.

Gregory of , St., Ad Ablabium, in: Patrologiae Cursus Completus. Series Graecae, ed. P. Migne, vol. 45, t. II, Paris 1863, c. 115-136.

Hryniewicz W., Duch Święty - Mistagog Bożego Królestwa, in: P. Evdokimov, Duch Święty w tradycji prawosławnej, transl. M. Żurowska, Poznań 2012, p. 7-25.

John Paul II, Encyclical “Dominum et vivificantem” (1986).

Jüngel E., Gott als Geheimnis der Welt, Tübingen 1977.

Kasper W., Bóg Jezusa Chrystusa, transl. J. Tyrawa, Wrocław 1996.

Laurentin R., Nieznany Duch Święty. Odkrywanie Jego doświadczenia i Jego Osoby, transl. M. Tarnowska, Kraków 1998.

Leśniewski K., ,, Kim jest człowiek, że o nim pamiętasz...? ” Podstawowe idee antropologii prawosławnej, Lublin 2015.

Maximus the Confessor St., Orationis dominicae brevis exposition, in: Patrologiae Cursus Completus. Series Graecae, ed. P. Migne, vol. 90, Paris 1865, c. 871-910.

Małecki R., Kościół jako wspólnota. Dogmatyczno-ekumeniczne studium eklezjologii Johna Zizioulasa, Lublin 2000.

Piotrowski E., Traktat o Trójcy Świętej, Warszawa 2007.

Strumiłowski J., Między Bogiem a człowiekiem. Teologia relacji w kontekście późnej nowoczesności, Kraków 2018.

Stubenrauch B., Pneumatologia - traktat o Duchu Świętym, Kraków 1999.

Werbick J., Trinitätslehre, in: Handbuch der Dogmatik, ed. T. Schneider, vol. 2, Düsseldorf 2000, p. 481-576.

Zizioulas J.D., Being as Communion. Studies in Personhood and the Church, New York 1985.

Zizioulas J.D., Communion and Otherness. Further Studies in Personhood and the Church, London-New York 2006.

Zizioulas J.D., Lectures in Christian Dogmatics, London-New York 2009.

Zizioulas J.D., The Eucharistic Communion and the World, London-New York 2011. 
Keywords: Holy Trinity, Holy Spirit, Communion, pneumatology, Filioque KOMUNIJNE ASPEKTY NAUKI O DUCHU ŚWIĘTYM WEDŁUG JOHNA D. ZIZIOULASA

Streszczenie

W myśli teologicznej Johna D. Zizioulasa na podkreślenie zasługuje jego otwartość ekumeniczna i głęboka teologia przesycona myślą komunijną, owocującą także komunijnym spojrzeniem na rzeczywistość Ducha Świętego. Prezentowany artykuł omawia trynitarno-eklezjalne początki pneumatologii, ważną dla niej koncepcję Komunii Osób Trójcy Świętej, a potem prawosławną ocenę trynitarnej koncepcji św. Augustyna i komunijne spojrzenie na Filioque - wraz z ekumenicznymi perspektywami tego zagadnienia.

Słowa kluczowe: Trójca Święta, Duch Święty, Komunia, pneumatologia, Filioque 